\title{
4 On the numerous concepts in invasion biology
}

\author{
6 Jannike Falk-Petersen ${ }^{1, *}$, Thomas Bøhn ${ }^{2} \&$ Odd Terje Sandlund ${ }^{3}$ \\ $7{ }^{1}$ Norwegian College of Fishery Science, University of Tromsø, NO-9037, Tromsø, Norway; ${ }^{2}$ Norwegian \\ 8 Institute of Gene Ecology, The Science Park, 6418, NO-9294, Tromsø, Norway; ${ }^{3}$ Norwegian Institute for \\ 9 Nature Research, Tungasletta 2, NO-7485, Trondheim, Norway; *Author for correspondence (e-mail: jan- \\ 10 nikefa@hotmail.com; fax:+47-776-46020)
}

11 Received 26 May 2005; accepted in revised form 11 July 2005

12 Key words: alien, concepts, exotic, indigenous, introduced, invasion, invasive, native, pest

\section{Abstract}

14 The study of biological invasions has triggered the production of a diversity of concepts. The terminology

15 has, however, often been applied inconsistently and inaccurately. This article lists and assesses the most

16 commonly used terms and concepts in invasion ecology. In each case the most coherent definition and use is

17 suggested.

21 ...very many (probably several hundred) square 22 miles are covered with one mass of these prickly 23 plants, and are impenetrable by man or beast.

24 Over the undulating plains, where these great beds 25 occur, nothing else can live. Charles Darwin "The 26 voyage of the beagle" 1839

\section{Introduction}

28 Over the last two centuries, the phenomenon of 29 biological invasions has been elevated from an 30 unavoidable, but not very serious, spin-off of hu31 man activities, to a serious encroachment on eco32 logical integrity. The historical expansion of the 33 relevance of invasion biology, and the associated 34 trend towards homogenization and reduction of 35 global biodiversity has even justified publication 36 of an entire scientific journal devoted to this topic 37 (Biological Invasions). This expansion has also 38 triggered the production of a diversity of concepts.

39 A number of authors have pointed out that

40 the terminology related to non-native species has often been applied inconsistently (Pyšek 1995; Mack 1996; Schwartz 1996; Bullock 1997, Richardson et al. 2000; CBD 2001; Marco et al. 2002; Kowarik 2003). This has lead to confusion in defining biological invasions. A common goal should be to reach conceptual agreement not only in the scientific literature, but also in how to interpret conservation treaties and laws in order to make sensible management priorities (Richardson et al. 2000; CBD 2001; Marco et al. 2002). The lack of clear definitions has also been identified as a contributing factor behind the slow progress made in invasion ecology over the past 40 years (Davis and Thompson 2000). In fact, the scientific literature on invasion ecology seems to be particularly well endowed with synonyms. Moreover, the terms used are often value laden and associative, for example when organisms are termed pests, weeds, or emerging diseases (e.g. Moore 1999; Hayes and Sliwa 2003). Words and expressions coined by various stakeholder groups have added further to the confusion.

\begin{tabular}{l|lll|} 
Journal : BINV & Dispatch : 28-7-2005 & Pages : $\mathbf{1 6}$ \\
CMS No. : DO00020710 & $\varangle$ LE & $\square$ TYPESET \\
MS Code : BINV 246R1 & $\square$ CP & $\square$ DISK \\
\hline
\end{tabular}


64 Terms and concepts always contain and imply 65 more than the definitions provided by dictionar66 ies, or the scientific literature. Interpretations and 67 symbolic meanings follow all terms, differing be68 tween scientific schools or cultural contexts, and 69 evolving over time. Nevertheless, terms and con70 cepts represent the basis for communication of 71 knowledge and understanding. It is therefore 72 worth nearly every effort to reach for precise def73 initions, and also to follow a stringent line of 74 consistent use.

75 Although attempts have been made to clarify 76 the terms related to alien species (ex. Mühlenbach 77 1979; Pyšek 1995; Williamson and Fitter 1996;

78 Richardson et al. 2000; Davis and Thompson 79 2000; Daehler 2001) invasion ecology is still bur-

80 dened by inaccurate use of concepts. In this article

81 we list and assess the most commonly used terms 82 and concepts in invasion ecology. In each case the 83 most coherent definition and use is suggested.

\section{Approach}

85 A literature study was conducted recording defi86 nitions of terms and concepts related to biological 87 invasions and non-native organisms. Biological 88 dictionaries, international treaties, and publica- tions in scientific journals were examined. As far as possible, the primary source of the definitions was identified. The focus has been on relatively recent literature (past 30 years) and on English language literature to avoid confusion due to translation. Emphasis was put on terms that are not specific to any particular taxonomic group.

\section{Results and discussion}

Overview

The field of invasion biology has expanded beyond the 'classical biology' that concerns organisms within their natural distribution (Figure 1). The discipline of invasion biology deals with traits of introduced non-native species, their ability to spread, their interactions with each other and with native species in receiving ecosystems Table 1.

We selected 145 definitions related to invasion biology and non-native organisms (Appendix A.1). Out of these definitions, 102 were general and 43 were specific to taxonomic or other groups. The taxonomic groups listed in the definitions are plants (31), animals (15), pests (6),
89

90

91

92

93

94
NATIVE

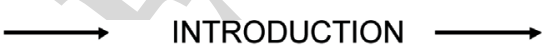

NON-NATIVE

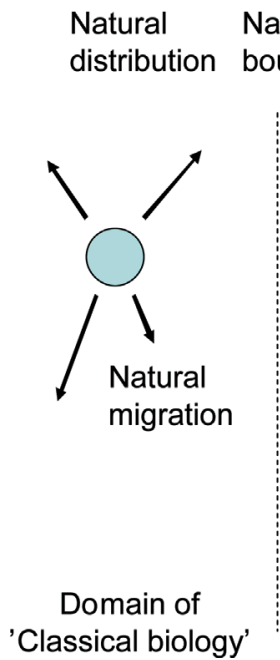

\section{Natural} boundary

\section{Receiving ecosystems}

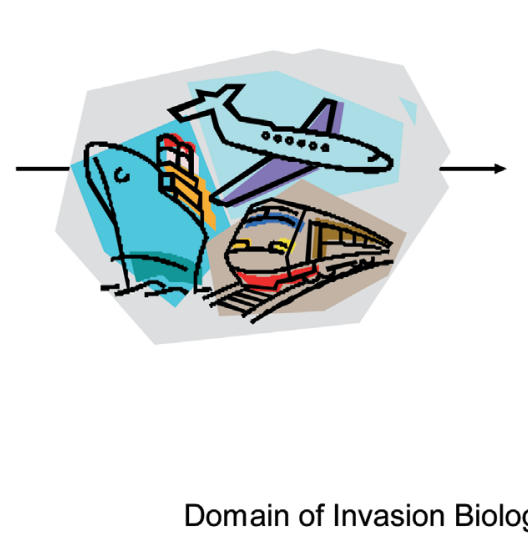

Figure 1. Schematic overview over the domains and main elements of 'Classical biology' vs 'Invasion biology'.

\begin{tabular}{|l|lll|}
\hline & Journal : BINV & Dispatch : 28-7-2005 & Pages : $\mathbf{1 6}$ \\
CMS No. : Do00020710 & $\varangle$ LE & $\square$ TYPESET \\
MS Code: BINV 246R1 & $\varangle$ CP & $\square$ DISK \\
\hline
\end{tabular}




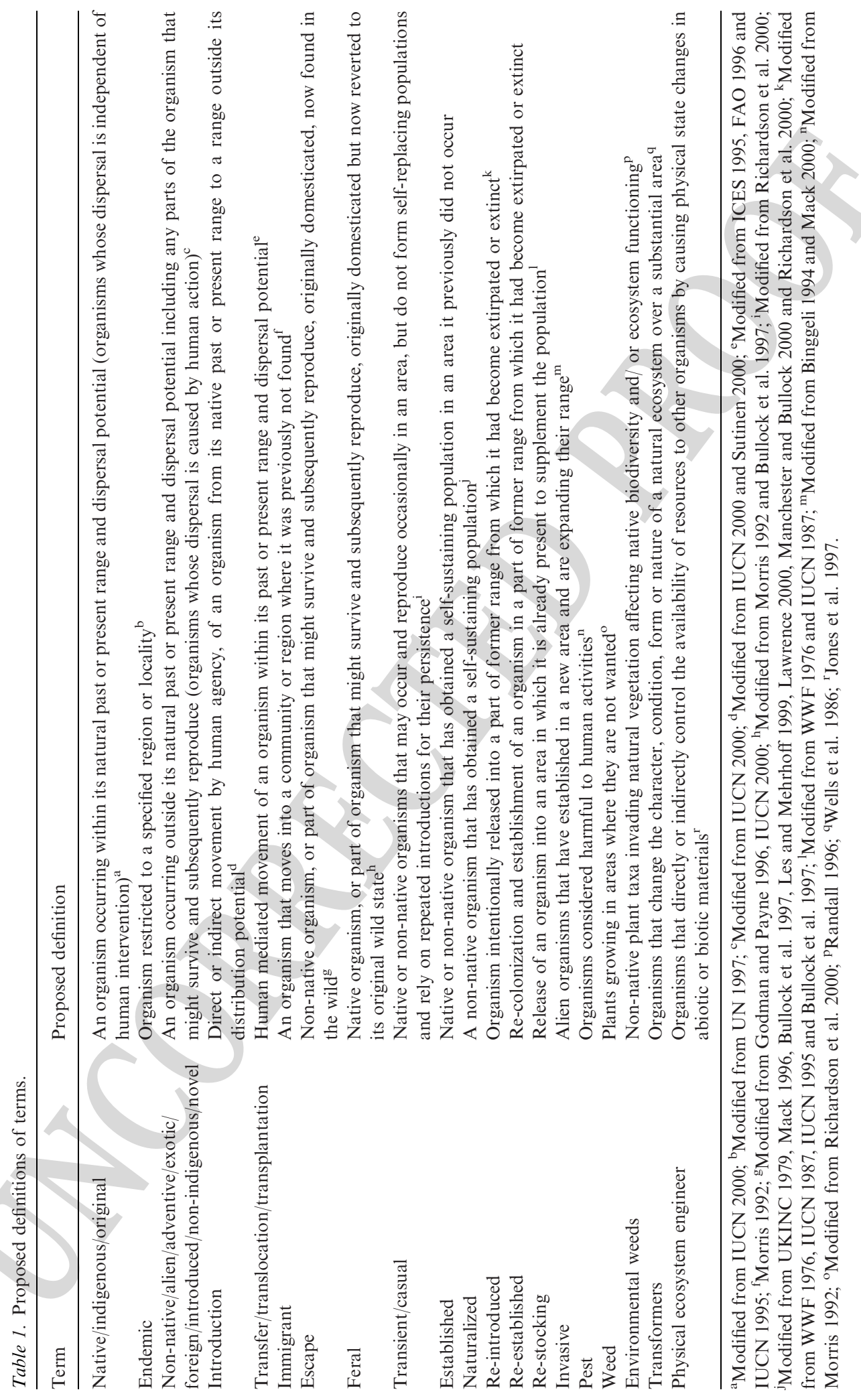

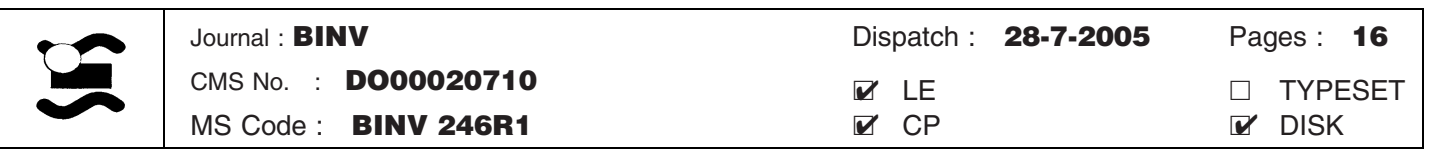




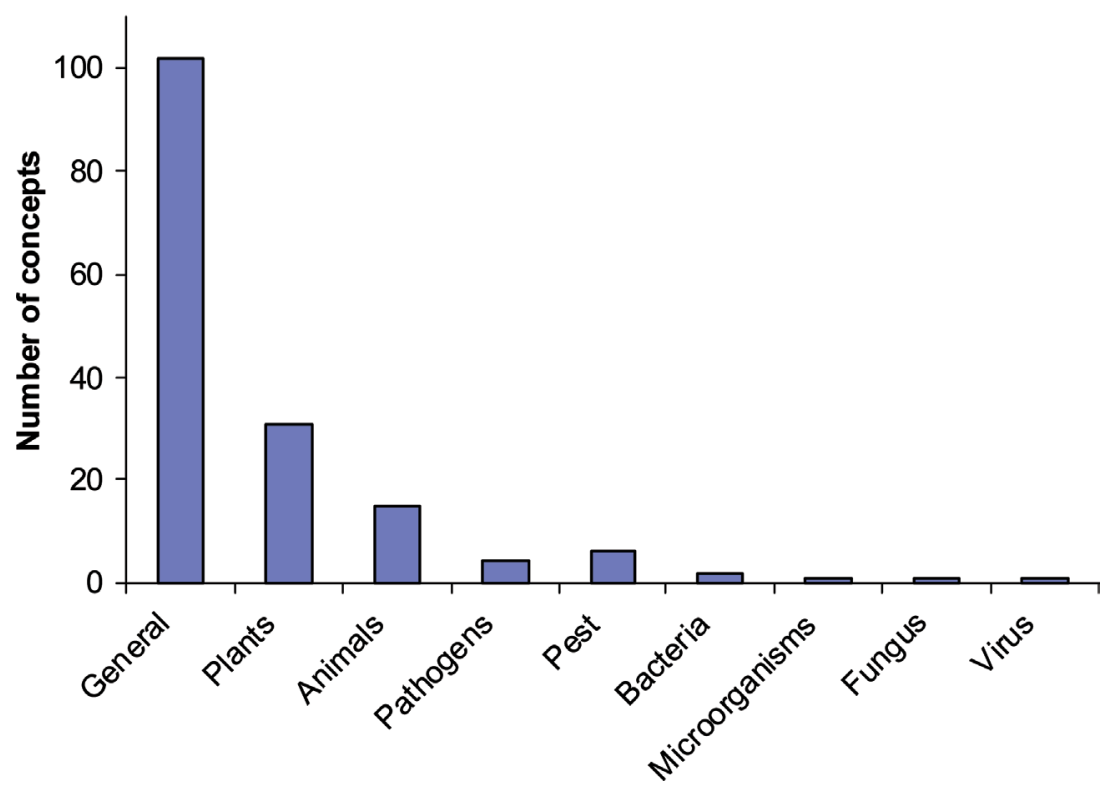

Figure 2. Number of general and specific definitions of non-native organisms found in literature.

112 pathogens (4), bacteria (2) and fungus, micro113 organisms and virus (1) (Figure 2). 11 of the defi114 nitions list more than one group.

\section{Suggested terms of use}

\section{Native/indigenous/original}

117 Out of ten definitions, three refer to the organ-

118 ism's distribution in relation to its dispersal abil-

119 ity and three to presence previous to a defined

120 time period. Six definitions classify indigenous

121 species as those whose present distribution is

122 independent of humans, while three only refer to

123 undefined criteria such as 'occurring naturally'.

124 Since natural communities are dynamic and 125 continuously expand or retract their spatial dis-

126 tribution, it may in practice be difficult to distin-

127 guish native species (existing in an area due to

128 their own means of dispersal) from those that

129 have been introduced through human interven-

130 tions. Classification of a species being native or

131 alien has often been based on a variety of crite-

132 ria, including emotional views, misinterpretations

133 of fossil records, intuitive arguments, and uncriti-

134 cal acceptance of earlier classification (Webb

135 1985).

136 Webb (1985) suggested that those species that

137 arrived before the beginning of the Neolithic period (about 7-8000 years BP) should be considered native species. Before the introduction of farming and animal husbandry, humans were an agent of dispersal equivalent to that of other animals. Other authors consider as native those species that have been present in prehistoric times, or since the last glaciation (about 14000 BP) (Binggeli 1994; NCC 1990 as in Bullock et al. 1997; Manchester and Bullock 2000). Les and Mehrhoff (1999) applied case specific definitions when looking at impacts of plant introductions subsequent to European settlement in New England. They defined indigenous species as those occurring in southern New England prior to 1496 AD, when the first European explorer came to the region. Problems of using specific temporal criteria include human-aided dispersal of organisms prior to the proposed dates and the lack of data to determine actual historical status (Schwartz 1996).

Common to all these definitions is the recognition that at some point in the past, humans no longer acted as natural dispersal agents, but became the driving force reshuffling species beyond their dispersal limitations. Although the definitions vary, and even if the practical determination of the native status of a specific species can be problematic, the meaning of the terms

\begin{tabular}{|l|lll|}
\hline & Journal : BINV & Dispatch : 28-7-2005 & Pages : $\mathbf{1 6}$ \\
CMS No. : Do00020710 & $\square$ LE & $\square$ TYPESET \\
MS Code: BINV 246R1 & $\nabla$ CP & $\square$ DISK \\
\hline
\end{tabular}


166 denoting naturally occurring species does not

167 appear to be controversial. Native species are

168 those whose distribution is independent of hu-

169 mans.

\section{Endemic}

171 Endemic is a more restricted term, denoting a 172 species that occurs only in a restricted region 173 (eight of eight definitions). The geographic scale 174 of 'restricted area' will obviously influence the 175 degree to which an endemic species differs from a 176 native species.

177 Non-native/alien/adventive/exotic/foreign/non-

178 indigenous/novel

179 We were able to identify 20 definitions of

180 non-native organisms. Morris (1992) defines the

181 term 'exotic' merely with reference to synonyms

182 ('foreign' and 'not native'). Three of the defini-

183 tions refer to absence of the organism prior to a

184 certain time period, 13 to the distribution of the

185 organism being human mediated, two to the imp-

186 act of the organism in the new area, and four to

187 the extent that the species has established

188 self-reproducing populations. The two last factors

189 are better covered by other terms related to non-

190 native species. A definition based on IUCN

191 (2000) is preferred, referring to the presence of an

192 organism outside its dispersal potential. From

193 this it is followed that non-native organisms are

194 those whose distribution has been mitigated by

195 humans. The term 'adventive' is not commonly

196 used, with only three, non-conclusive definitions

197 found in literature (Morris 1992; Bingelli 1994;

198 Lawrence 2000). We suggest the term as a

199 synonym to terms describing non-native species.

200 Manchester and Bullock (2000) separate

201 organisms whose dispersal has been mediated by

202 humans (non-native, alien, non-indigenous) and

203 those translocated independent of human activity

204 (exotic). In our opinion 'translocated' implies an

205 external agent, and we would recommend that

206 the term 'immigrant' is better suited to denote

207 organisms that become established in a new area

208 independent of human introductions, i.e. through

209 their own migratory abilities.

210 Davis and Thompson (2000) discourage the

211 use of terms like 'alien' and 'exotic' as their con-

212 notations could indicate that these species are governed by different ecological processes than natural immigrants. However, the terms do not refer to the ecological processes, but rather that there is an anthropogenic action that, directly or indirectly, causes the appearance of the non-native species. Moreover, we agree with Daehler (2001) that terms used in ecology not necessarily need to match their common English definition. The important factor is that they capture the ecological concept, and are given a precise definition.

\section{Introduction/introduced}

The terms 'introduction' and 'introduced' were in 17 out of 20 cases defined as non-native organisms intentionally or accidentally transferred by human agency. While 'introduction' is an act, 'introduced species' is a synonym to non-native species as indicated by four of the references (Bingelly 1994; ICES 1995; FAO 1996; Sutinen 2000).

Out of the 20 definitions, three include the degree of establishment. IPPC (1997) and FAO (2000) define introduction as 'the entry of a pest leading to its establishment'. Establishment, or naturalization, does not necessarily follow the introduction of an organism. In fact, in most cases of introduction, the species does not establish self-reproducing populations (Williamson 1996). Furthermore, the word 'pest' is highly subjective and not only applicable to non-native organisms (but see below). Williamson and Fitter (1996) define 'introduced' as being synonymous to 'feral' and 'casual'. However, these terms have other meanings, as described below.

Introductions act on regional to continental scales, when barriers between native and new ranges are crossed (Kowarik 2003). In addition to 'introduction', Kowarik (2003) uses the expression 'secondary releases' when species are moved within the new range. The criteria for using 'secondary release' instead of 'introduction' may be somewhat arbitrary, but under certain conditions this may be a useful distinction. A relevant example is the introduction of the North American signal crayfish (Pasifastacus leniusculus) to Europe (Italy) in the 1860s. To compensate for over-harvesting of the native crayfish species (Astacus astacus and others),

\begin{tabular}{|l|lll|}
\hline Journal : BINV & Dispatch : 28-7-2005 & Pages : 16 \\
CMS No. : Do00020710 & $\nabla$ LE & TYPESET \\
MS Code : BINV 246R1 & $\nabla$ CP & DISK \\
\hline
\end{tabular}


261 signal crayfish from introduced stocks in Italy 262 and elsewhere subsequently became subject to 263 secondary releases in ever new freshwater sys264 tems over most of Europe (Sandlund and Bon265 gard 2000).

\section{Transferred/translocated/transplanted}

267 Organisms that have been moved by humans 268 within their present ranges have been referred to 269 as 'transferred species' (ICES 1995; FAO 1996). 270 Translocation has been defined as movement of 271 an organism from one place to another (Bullock 272 et al. 1997 based on NCC 1990; Lawrence 2000), 273 and as movement within the organism's range 274 (IUCN 1995). A transplanted organism has also 275 been defined in terms of being moved from one 276 place to another (Morris 1992), as well as being 277 transported and released within its present range 278 (ICES 1995). The definitions of translocated and 279 transplanted are few and not very precise. We 280 propose that the terms 'transferred', 'translocat281 ed' and 'transplanted' should be used to describe 282 human mediated movement of species within 283 their native range, whereas 'introduced' should 284 be used when species are moved beyond their 285 natural range and dispersal potential.

\section{Immigrant}

287 Lawrence (2000) defines immigrant species as 288 those that migrate into an ecosystem, or are 289 introduced by humans. The latter situation is 290 covered by 'introduced species', and 'immigrant 291 species' should be reserved to cover species that 292 move into a new area without the aid of humans.

\section{Escaped/feral (for domesticated species)}

294 Escaped organisms have been defined as plants 295 or animals originally domesticated that are found 296 in the wild. While the definitions of 'escape' do 297 not refer to the origin of the organism, three out 298 of five definitions of 'feral' specify that the 299 organisms have reverted to their wild state. We 300 suggest that 'escape' should refer to non-native, 301 while 'feral' should refer to native organisms that 302 following escape or release from domestication 303 now live in the wild. The degree of establishment 304 is included in some of the definitions of escaped 305 and feral organisms. To prevent overlapping of meaning of terms, degree of establishment should be specified using separate terms.

\section{Transient/casual}

Species that do not form self-sustaining populations may generally be termed transient or casual. Thus, the terms may apply to both native species in marginal non-permanent populations, to immigrant species occurring somewhere for a limited period of time, and to non-native species whose persistence rely on repeated introductions. The latter group may be referred to as 'transient non-native' or 'casual non-native' (Mack 1996; Richardson et al. 2000). We would recommend that the terms 'transient' and 'casual' may be used for all the three situations above, but always together with a qualifying term like, e.g., 'non-native'.

Naturalized/established

Both terms refer to organisms that have established a self-sustaining population.

All of the ten definitions found in literature specify that a naturalized species is novel to the region. 'Naturalized' should be used to describe non-native organisms that have established as self sustaining populations. Thus, naturalization is the outcome of an establishment process of nonnative organisms (Holmes and Stroud 1995). Allaby (1998) defines a naturalized species as a non-native that has invaded a native community, while Mack (1996) and Richardson et al. (2000) stress that the occurrence of a naturalized organism may not develop into an invasion. The latter use is recommended as it reduces overlap between a weaker term, 'naturalized' and a stronger term, 'invasion'. Holmes and Stroud (1995) suggest further specifications of naturalization according to whether the species was originally domesticated, non-domestic naturally occurring, or non-native.

'Established' has been used to refer solely to pest organisms (three out of six definitions), one refer to organisms deliberately transferred from one area to another (non-native) while two definitions do not specify. We suggest that 'established' should be used as a general ecological term referring to both native and non-native organisms that have obtained self-sustaining populations.

\begin{tabular}{|l|lll|}
\hline Journal : BINV & Dispatch : 28-7-2005 & Pages : 16 \\
CMS No. : Do00020710 & $\square$ LE & $\square$ TYPESET \\
MS Code : BINV 246R1 & $\nabla$ CP & DISK \\
\hline
\end{tabular}


353 Re-introduction/re-establishment/re-stocking

354 The term 're-introduced' is defined as the inten355 tional release of organisms into a part of their 356 former natural range (six out of six definitions).

357 Holmes and Stroud (1995), however, claim that 358 re-introduction implies that the species was intro359 duced in the first place and suggest 're-estab360 lished' as a more precise term. We suggest that 361 're-introduced' should be used to mean introduc362 tion of organisms into a part of former natural 363 range from where it has been extirpated. 364 'Re-established' should mean that the species 365 itself manages to re-colonize a former area; and 366 that 're-stocking' should cover releases of organ367 isms to supplement wild populations already 368 present (four out of four definitions), like, e.g., 369 the common practice when fish species for recre370 ational purposes are re-stocked into localities 371 where the harvest is above a sustainable level.

372 Invasion/invasive

373 An invasion is a colonization process, but it is

374 distinguished from succession ('a natural change

375 in the structure and species composition of a

376 community' (Chapman and Reiss 1999)) by being

377 restricted to describe the spread of a non-native

378 organism. 'Invasion' can be used synonymously

379 to 'secondary spread'.

380 In the literature, 'invasive' has largely been used 381 to deal with alien or non-native species (Pyšek 382 1995; Richardson et al. 2000). Invasive organisms 383 have established and are expanding their range in 384 an area where they previously did not occur. Out 385 of 14 references, 11 specify that invasive organ386 isms are non-native, and eight that the invasion 387 has a negative effect on the native community. 388 Eight references specify that invasive organisms 389 expand their range. We suggest that the word 390 'invasive' should be used to refer only to non-na391 tive organisms that expand their range on their 392 own accord. This makes it relevant to define and 393 specify invasive traits, such as the ability to 394 spread, strong competitive ability, etc. Any organ395 ism entering a new area will have an effect on their 396 new community. The consequences of invasions 397 and how they are perceived should, however, not 398 be included in the definition of 'invasive', but 399 rather be expressed by other terms (see below).

400 Pyšek (1995) suggests that invasive species 401 should be used as synonymous to alien, due to difficulties related to, and a general lack of, studies documenting spread of aliens. Regardless of this (somewhat peculiar) argument, he suggests to define invasive as aliens whose abundance is increasing. Furthermore, he suggests that 'invasive' is synonymous to 'naturalized'. As argued above, a naturalized species need not become invasive.

Richardson et al. (2000) define the invasive status of plants according to rate of spread ( $>100 \mathrm{~m}$ in $<50$ years for taxa spreading by seeds and other propagules, $>6 \mathrm{~m}$ per 3 years for taxa spreading by roots, rhizomes, stolons, or creeping stems). Although these criteria are fairly arbitrary, they can be useful in practice when defining the invasive status within a comparable group of plants. These criteria are obviously not appropriate for all taxa as the potential rate and degree of spread differ significantly between organisms. Defining measurable criteria of invasive status must therefore be seen in relation to the potential growth and rate of spread of the organism concerned. The distinction between non-invasive and invasive can, however, be imprecise, as spread is partly a function of time since establishment, which is often unknown (Kolar and Lodge 2001).

The term 'invasive' is now generally accepted in international management activities relating to this issue as an environmental problem, as the expression 'invasive alien species (IAS) is generally used by both the Convention on Biological Diversity (CBD; http://www.biodiv.org), the Global Invasive Species Programme (GISP; http:// www.gisp.org), and by IUCN's Invasive Species Specialist Group (http://www.issg.org).

\section{Pest/weed /harmful-, nuisance-species/problem} plants/biological pollutants

Some authors claim that introduced species may not have significant impact on the native ecosystem (Mooney and Hobbs 2000; FAO 2003). Considering all the possible direct and indirect interactions in an ecosystem, it is hard to see that a novel organism will not have any effect at all on the new system. But effects clearly range from barely detectable to large scale alterations with displacement or loss of biodiversity, reduction in economic value, etc. The assessment of negative effects is always determined by the focus and scale
402

403

404

405

406

407

408

409

410

411

412

413

414

415

416

417

418

419

420

421

422

423

424

425

426

427

428

429

430

431

432

433

434

435

436

437

438

439

440

441

442

443

444

445

446

447

448

449

450

\begin{tabular}{|l|lll|}
\hline & Journal : BINV & Dispatch : 28-7-2005 & Pages : $\mathbf{1 6}$ \\
CMS No. : DO00020710 & $\square$ LE & $\square$ TYPESET \\
MS Code : BINV 246R1 & $\square$ CP & $\varnothing$ DISK \\
\hline
\end{tabular}


451 of study as well as social and economic conse452 quences. This is further complicated by the often 453 diverging values of interest groups. Furthermore, 454 the perception of the non-native organism may 455 change over time (Starfinger et al. 2003). The 456 evaluation of the effects of non-native organisms 457 has triggered the use of terms such as 'pest', or 458 'weed'. Other less common terms include 'harmful 459 species', 'nuisance species', 'problem plants' and 460 'biological pollutants'.

461 'Pest' and 'weed' are subjective terms describ462 ing any organism regarded as harmful/having 463 negative effects. Pests have been defined as 464 organisms being unpleasant to humans (seven 465 out of 12 definitions), detrimental to plants, 466 plant products or crops (eight out of 12 defini467 tions), harmful to animals (one out of 12 defini468 tions), and to the environment in general (one 469 out of 12 definitions).

470 Three out of 12 definitions of "pest" describe 471 animals as pests, three of 12 describe plants as 472 pests, and seven of 12 concern organisms in gen473 eral as pests. We suggest a definition that includes 474 organisms that are invasive, and directly or indi475 rectly have a negative effect on humans or are 476 perceived as unwanted in terms of economy, 477 health, or environment. This definition is non478 exclusive when it comes to taxonomic reference 479 and is in accordance with the majority of the defi480 nitions, stressing the impact on human well being. 481 'Weeds' refer specifically to undesirable plants (all 482 five definitions). Only Godman and Payne (1996) 483 restrict weeds to be plants growing in cultivated 484 areas. Rather than restricting the definition to 485 anthropogenically altered areas, one might specify 486 the habitat where a specific organism is undesir487 able. The terms 'pest' and 'weed' may be applied 488 both to non-native and native organisms.

489 The definition of pest has been criticized for 490 being socio-economically based and therefore 491 having a tenuous ecological meaning. The terms 492 'pest' and 'weed' are based on societal or socio493 economic values and we suggest that their use 494 should be followed by a more detailed descrip495 tion of what kind of pest an organism represent, 496 and for whom. For example, for local farmers an 497 introduced or native plant or insect may become 498 a pest requiring a certain management response, 499 including costs and benefits.
Transformer/ecosystem engineer/environmental 500 weeds

Terms only describing ecological processes include 'transformers', 'ecosystem engineers' and 'environmental weeds'. 'Transformers' are organisms that change the character, condition, form or nature of ecosystems over a substantial area relative to the extent of that ecosystem (Wells et al. 1986). Organisms controlling the availability of resources to other organisms by causing physical state changes are referred to as 'Physical ecosystem engineers' (Jones et al. 1997). Although used in the context of non-native organisms (Wells et al. 1986; Crooks 2002), the terms are not specifically defined to be restricted to non-native organisms. 'Environmental weeds' are specified to be non-native plants affecting biodiversity and/or ecosystem functioning (Humphries et al 1991 as in Randall 1996). All three terms describe organisms that have clear ecosystem impacts and therefore should receive extra attention.

\section{Conclusion}

The growing scientific field of invasion biology has suffered from its often confusing use of terms. Synonyms have been too many, many terms have not been properly defined, and the use of terms and concepts has not been consistent. Further, the definitions of terms have been related to specific taxonomic groups, most often plants. This may have created more taxonomic barriers (e.g. plants vs animals) than necessary between invasion biologists and thus reduced valuable communication. When discussing biological invasions in general terms, it is important to use terms that include all types of organisms rather than more specific terms. The generality (or specificity) of the knowledge should be reflected in the generality (or specificity) of the concepts.

Conceptual confusion, value laden terms, and taxonomy-based barriers within the field of invasion biology are all unnecessary and will lead to a reduced generality of the conclusions drawn. We encourage all invasion biologists to tighten up their use of terms and concepts for a common goal of clarity, and also to be explicit in defining their terms and concepts.

\section{1}

503

504

505

506

507

508

509

510

511

512

513

514

515

516

517

518

519

520

522

523

524

525

526

527

528

529

530

531

532

533

534

535

536

537

538

539

540

541

542

543

544

545

\begin{tabular}{|l|lll|}
\hline Journal : BINV & Dispatch : 28-7-2005 & Pages : 16 \\
CMS No. : Do00020710 & $\square$ LE & TYPESET \\
MS Code : BINV 246R1 & $\square$ CP & DISK \\
\hline
\end{tabular}




\section{Appendix A}

547 Appendix A.1. Overview of the 145 selected concepts and definitions as used in the literature, sorted to 10 main categories.

\begin{tabular}{|c|c|c|}
\hline Term & Definition & Reference \\
\hline Indigenous & $\begin{array}{l}\text { Describes an organism growing naturally in the area, rather } \\
\text { than one that has been introduced }\end{array}$ & Godman and Payne 1986 \\
\hline Indigenous species & $\begin{array}{l}\text { A native species which is not necessarily restricted in its dis- } \\
\text { tribution to a particular lake, drainage system or biogeo- } \\
\text { graphical region. A species which naturally occur in southern } \\
\text { Africa as well as in other parts of Africa is therefore indigenous } \\
\text { to southern Africa but not endemic to that region }\end{array}$ & Moor and Bruton 1988 \\
\hline Indigenous & Belonging to the locality/native/not imported & Lawrence 2000 \\
\hline Indigenous, native, original & Native to or occurring naturally in a particular area & Morris 1992 \\
\hline Indigenous, native & Species naturally occurring in an area since prehistorical time & Binggeli 1994 \\
\hline Indigenous, native & $\begin{array}{l}\text { Species that occurs naturally in an area, and therefore one that } \\
\text { has not been introduced by humans either accidentally or } \\
\text { intentionally }\end{array}$ & Allaby 1998 \\
\hline Indigenous, native & Species, subspecies, or lower taxon, occurring within its natural & IUCN 2000 \\
\hline
\end{tabular}

Indigenous, native range (past or present) and dispersal potential (i.e. within the range it occupies naturally or could occupy without direct or indirect introduction or care by humans)

Species or race that occurs naturally in an area, i.e. whose dispersal has occurred independently of deliberate human translocation (generally a species or race thought to have occurred in an area since before the Neolithic)

Native

A species or race which occurs naturally in an area...whose dispersal has occurred independently of human activity. Usually organism thought to have occurred since prehistoric times

Native

Endemic

Endemic species

Endemic species

Endemic species

Endemic

Animals and plants which originate in a district or area in which they live

Peculiar to and characteristic of locality or region

Species restricted to a specified region or locality

Pest or pathogen limited to a certain region or occurring continuously in a given region

A species that is restricted in its distribution to a particular lake, drainage system or biogeographical region

Of or relating to a native species or population occurring under highly restricted conditions due to the presence of a unique environmental factor that limits its distribution

Endemic

A species, race or other taxon that is restricted to a particular country or region

Endemism

The situation in which a species or other taxonomic group is restricted to a particular geographic region, owing to factors such as isolation or response to soil or climatic conditions Restricted to a certain region or part of region

Endemic

Adventive

Adventive, invasive, naturalized, neophyte

Adventive

Alien, introduced, exotic

An organism artificially or accidentally introduced into an environment where it is not native

The establishment of self-regenerating, usually expanding, populations of an introduced species in a free-living state in the wild

Organism in a new habitat but not completely established there/ non-native

Deliberate or accidental release of a species into an area in which it has not occurred in historical times

Alien

Plant species thought to have been introduced by humans but now more or less naturalized

Alien

Bullock et al. 1997

Lawrence 2000

Allred and Clements 1949

UN 1997

Godman and Payne 1986

Moor and Bruton 1988

Morris 1992

Bullock et al. 1997

Allaby 1998

Lawrence 2000

Morris 1992

Binggeli 1994

Lawrence 2000

Bingelly 1994

Lawrence 2000

GBWMP-SA 2004

\begin{tabular}{|l|lll|}
\hline & Journal : BINV & Dispatch : 28-7-2005 & Pages : $\mathbf{1 6}$ \\
CMS No. : Do00020710 & $\square$ LE & $\square$ TYPESET \\
MS Code : BINV 246R1 & $\nabla$ CP & DISK \\
\hline
\end{tabular}


Appendix A.1. Continued.

\begin{tabular}{|c|c|c|}
\hline Term & Definition & Reference \\
\hline Alien & An introduced species from outside the boundaries of southern Africa & Moor and Bruton 1988 \\
\hline Alien, exotic & An introduced species & UKINC 1979 \\
\hline $\begin{array}{l}\text { Alien, non-native, } \\
\text { non-indigenous, } \\
\text { foreign, exotic species }\end{array}$ & $\begin{array}{l}\text { Species, subspecies, or lower taxon occurring outside its natural range } \\
\text { (past or present) and dispersal potential (i.e. outside the range it } \\
\text { occupies naturally or could not occupy without direct or indirect } \\
\text { introduction or care by humans) and includes any part, gamets or } \\
\text { propagule of such species that might survive and subsequently repro- } \\
\text { duce }\end{array}$ & IUCN 2000 \\
\hline $\begin{array}{l}\text { Alien, non-indigenous, } \\
\text { non-native, exotic }\end{array}$ & $\begin{array}{l}\text { Species or race that does not occur naturally in an area, i.e. it has not } \\
\text { previously occurred there, or its dispersal into the area has been } \\
\text { mediated by humans. Usually assumed that species that have colonized } \\
\text { since the Neolithic are non-native. }\end{array}$ & Manchester and Bullock 2000 \\
\hline $\begin{array}{l}\text { Alien, exotic, non-native, } \\
\text { non-indigenous plants }\end{array}$ & $\begin{array}{l}\text { Plant taxa in a given area whose presence is due to intentional or } \\
\text { accidental introduction as a result of human activity }\end{array}$ & Richardson et al. 2000 \\
\hline $\begin{array}{l}\text { Alien, introduced, exotic, } \\
\text { non-indigenous species }\end{array}$ & $\begin{array}{l}\text { A species that has been transported by human activity, intentional or } \\
\text { accidental, into a region where it does not naturally occur }\end{array}$ & Sutinen, J.G. 2000. \\
\hline Exotic & Of foreign origin; not native to the region in which it is found & Morris 1992 \\
\hline Exotic & $\begin{array}{l}\text { Not native to a particular country, ecosystem or ecoarea (applied to } \\
\text { organisms intentionally or accidentally introduced as a result of hu- } \\
\text { man activities) }\end{array}$ & ISPM 1996 \\
\hline Exotic species & $\begin{array}{l}\text { Species not native to a particular area which may pose a risk to en- } \\
\text { demic species. }\end{array}$ & UN 1997 \\
\hline Exotic & Foreign plant or animal which has not acclimatized or naturalized & Lawrence 2000 \\
\hline $\begin{array}{l}\text { Exotic, non-indigenous, } \\
\text { introduced species }\end{array}$ & $\begin{array}{l}\text { Any species intentionally or accidentally transported and released by } \\
\text { humans into an environment outside its present range }\end{array}$ & ICES 1995 \\
\hline Non-indigenous & $\begin{array}{l}\text { Those species that did not occur geographically within a particularly } \\
\text { defined region prior to some predetermined period }\end{array}$ & Les and Mehrhoff 1999 \\
\hline $\begin{array}{l}\text { Non-indigenous, exotic, } \\
\text { introduced species }\end{array}$ & $\begin{array}{l}\text { Any species intentionally or accidentally transported and released by } \\
\text { humans into an environment outside its present range }\end{array}$ & FAO 1996 \\
\hline Non-native & $\begin{array}{l}\text { A species or race that does not occur naturally in an area, i.e. it has } \\
\text { never occurred there or its dispersal into the area has been mediated by } \\
\text { humans. }\end{array}$ & Bullock et al. 1997 \\
\hline Introduced species & $\begin{array}{l}\text { Non-indigenous species/exotic species. Any species intentionally or } \\
\text { accidentally transported and released by humans into an environment } \\
\text { outside its present range }\end{array}$ & ICES 1994 \\
\hline Introduced species & $\begin{array}{l}\text { Any species intentionally or accidentally transported and released by } \\
\text { humans into an environment outside its present range }\end{array}$ & FAO 1996 \\
\hline Introduced & $\begin{array}{l}\text { Plants and animals not native to the country and thought to have been } \\
\text { brought in by humans }\end{array}$ & Lawrence 2000 \\
\hline Introduced species & $\begin{array}{l}\text { Any (non-indigenous) species intentionally or accidentally transported } \\
\text { and released by humans into an environment beyond its present range }\end{array}$ & FAO 2004 \\
\hline Introduced, alien, $e$ & $\begin{array}{l}\text { Deliberate or accidental release of a species into an area in which it has } \\
\text { not occurred in historical times }\end{array}$ & Binggeli 1994 \\
\hline $\begin{array}{l}\text { Introduced, exotic, } \\
\text { non-indigenous species }\end{array}$ & $\begin{array}{l}\text { Any species intentionally or accidentally transported and released by } \\
\text { humans into an environment outside its present range }\end{array}$ & ICES 1995 \\
\hline Introduced, feral, casual & $\begin{array}{l}\text { Found outside control or captivity as a potentially self-sustaining } \\
\text { population }\end{array}$ & Williamson and Fitter 1996 \\
\hline $\begin{array}{l}\text { Introduced, alien, exotic, } \\
\text { non-indigenous species }\end{array}$ & $\begin{array}{l}\text { A species that has been transported by human activity, intentional or } \\
\text { accidental, into a region where it does not naturally occur }\end{array}$ & Sutinen, J.G. 2000. \\
\hline Introduction & $\begin{array}{l}\text { Release of animals of a species into an area in which it has not oc- } \\
\text { curred }\end{array}$ & WWF 1976 \\
\hline Introduction & $\begin{array}{l}\text { The deliberate or accidental release of animals or plants of a species or } \\
\text { race into an area in which it has not occurred in historical times; or, a } \\
\text { species or race so released }\end{array}$ & UKINC 1979 \\
\hline
\end{tabular}


Appendix A.1. Continued.

\begin{tabular}{|c|c|c|}
\hline Term & Definition & Reference \\
\hline Introduction & $\begin{array}{l}\text { Intentional or accidental dispersal by human agency of a living } \\
\text { organism outside its historically known native range }\end{array}$ & IUCN 1987 \\
\hline Introduction & $\begin{array}{l}\text { The entry of a pest into a country or area where it does not } \\
\text { occur }\end{array}$ & FAO 1990 \\
\hline Introduction & $\begin{array}{l}\text { The deliberate or accidental release of living organisms into the } \\
\text { wild in areas where that kind of organism does not occur nat- } \\
\text { urally, and has not occurred since the last glaciation (or during } \\
\text { historic time) }\end{array}$ & $\begin{array}{l}\text { NCC } 1990 \text { as in Bullock } \\
\text { et al. } 1997\end{array}$ \\
\hline Introduction & $\begin{array}{l}\text { The deliberate or accidental release of an organism (s) into the } \\
\text { wild to areas (e.g. country, region, site, etc.) where the species or } \\
\text { race is not native. Applies also to the release of GMOs into the } \\
\text { wild }\end{array}$ & Bullock et al. 1997 \\
\hline Introduction & The entry of a pest resulting in its establishment & IPPC 1997 \\
\hline Introduction & $\begin{array}{l}\text { Movement, by human agency, of a species, subspecies or lower } \\
\text { taxon (including any part, gamets or propagule that might } \\
\text { survive and subsequently reproduce) outside its natural range } \\
\text { (past or present). The movement can be either within a country } \\
\text { or between countries }\end{array}$ & IUCN 2000 \\
\hline Introduction & $\begin{array}{l}\text { Deliberate or accidental release by human agency of an } \\
\text { organism into the wild by humans in areas where the species or }\end{array}$ & $\begin{array}{l}\text { Manchester and Bullock } \\
2000\end{array}$ \\
\hline
\end{tabular}

Introduction

Introduction

Introduced species

Transferred, transplanted species

Transferred, transplanted species

Translocation

Translocation

Translocation

Translocation

Translocated indigenous species

Transplanted

Transplant

Immigrant

Immigrant species

Escape

Escape

Escape

Escaping

Feral race is not native

Plant that has been transported by humans across a major geographic barrier

The entry of a pest resulting in its establishment

A species which has been distributed intentionally or unintentionally by man to areas beyond its native range of distribution

Any species intentionally or accidentally transported and released within its present range

Any species intentionally or accidentally transported and released by humans into an environment within its present range Movement of living organisms from one area with free release in another

Deliberate and mediated movement of wild individuals or populations from one part of their range to another

General term for the transfer by human agency of any organism(s) from one place to another

Movement or removal to a different place or habitat

A species naturally found within southern Africa but which has been translocated either intentionally or unintentionally by man into catchments in which it was not naturally distributed

To remove a plant from one place and put it in another To transfer a growing plant from one place to another

An organism that moves into a community or region where it was previously not found

Species that migrate into an ecosystem or are introduced accidentally or deliberately by humans

Plant originally cultivated, found growing wild

A usually cultivated plant growing wild in fields or by roadsides, generally surviving but not well naturalized

Plant or animal originally domesticated and now established in the wild

Transition from imported to introduced

Having escaped from a state of domestication and reverted to the original wild or untamed state/existing naturally in nature; not cultivated or domesticated
Richardson et al. 2000

FAO 2002

Moor and Bruton 1988

ICES 1995

FAO 1996

\section{IUCN 1987}

IUCN 1995

Bullock et al. 1997

Lawrence 2000

Moor and Bruton 1988

Godman and Payne 1986

Morris 1992

Morris 1992

Lawrence 2000

Godman and Payne 1986

Morris 1992

Lawrence 2000

Williamson and Fitter 1996 Morris 1992

\begin{tabular}{|l|lll|}
\hline & Journal : BINV & Dispatch : 28-7-2005 & Pages : $\mathbf{1 6}$ \\
CMS No. : Do00020710 & $\varangle$ LE & $\square$ TYPESET \\
MS Code: BINV 246R1 & $\varangle$ CP & $\square$ DISK \\
\hline
\end{tabular}


Appendix A.1. Continued.

\begin{tabular}{|c|c|c|}
\hline Term & Definition & Reference \\
\hline Feral & $\begin{array}{l}\text { An organism (or its descendants) that has been kept in } \\
\text { domestication, captivity (animals) or cultivation (plants) but } \\
\text { which, after escape or release, now lives in the wild state }\end{array}$ & Bullock et al. 1997 \\
\hline Feral & $\begin{array}{l}\text { Applied to a wild or undomesticated organism. Applied to wild } \\
\text { strains of an otherwise domesticated species or to an organism } \\
\text { that has reverted to a wild condition following escape from } \\
\text { captivity }\end{array}$ & Allaby 1998 \\
\hline Feral & Wild, or escaped from domestication and reverted to wild state & Lawrence 2000 \\
\hline Feral & $\begin{array}{l}\text { An organism (or its descendants) that has been kept in } \\
\text { domestication, captivity (animals) or cultivation (plants) but } \\
\text { which, following escape or release, not lives in the wild state. } \\
\text { Populations are not necessarily self-maintaining }\end{array}$ & Manchester and Bullock 2000 \\
\hline Casual alien plants & $\begin{array}{l}\text { Alien plants that may flourish and even reproduce occasionally } \\
\text { in an area, but which do not form self-replacing populations, } \\
\text { and which rely on repeated introductions for their persistence } \\
\text { (includes taxa labelled in the literature as wirfs, transients, } \\
\text { occasional escapes and persisting after cultivation) }\end{array}$ & Richardson et al. 2000 \\
\hline Casual & $\begin{array}{l}\text { Non-native plant which has been introduced but has not yet } \\
\text { become established as a wild plant, although occurring uncul- } \\
\text { tivated }\end{array}$ & Lawrence 2000 \\
\hline Transient & Alien species that leave no persistent descendants & Mack 1996 \\
\hline Established & $\begin{array}{l}\text { (Of organisms) to make a place a permanent home for oneself/ } \\
\text { to make strong, secure or permanent }\end{array}$ & Godman and Payne 1986 \\
\hline Established & $\begin{array}{l}\text { An introduced species which has established self-sustaining } \\
\text { populations in areas of natural or semi-natural vegetation or } \\
\text { habitat }\end{array}$ & Moor and Bruton 1988 \\
\hline Established & $\begin{array}{l}\text { An introduced pest, present in a country or area, multiplying } \\
\text { and expected to continue }\end{array}$ & FAO 1990 \\
\hline Established & Organism with a self-sustaining population, naturalized & Williamson and Fitter 1996 \\
\hline Establishment & $\begin{array}{l}\text { The formation of a self-sustaining population of the translo- } \\
\text { cated species, race or GMO, i.e. some of the organisms survive } \\
\text { to produce offspring }\end{array}$ & Bullock 1997 \\
\hline Establishment & $\begin{array}{l}\text { Perpetuation, for the foreseeable future, of a pest within an area } \\
\text { after entry }\end{array}$ & IPPC 1997 \\
\hline Establishment & $\begin{array}{l}\text { Perpetuation, for the foreseeable future, of a pest within an area } \\
\text { after entry }\end{array}$ & FAO 2002 \\
\hline Naturalization & $\begin{array}{l}\text { The establishment of self-regenerating populations of an } \\
\text { introduced species or race in a free-living state in the wild }\end{array}$ & UKINC 1979 \\
\hline Naturalized & $\begin{array}{l}\text { An introduced species which has established self-sustaining } \\
\text { populations in areas of natural or semi-natural vegetation or } \\
\text { habitat }\end{array}$ & Moor and Bruton 1988 \\
\hline Naturalized & $\begin{array}{l}\text { Alien species whose descendants have become permanent } \\
\text { members of the local flora (may not develop into an invasion) }\end{array}$ & Mack 1996 \\
\hline Naturalized & A non-native species or race which, after escape or release, has & Bullock et al. 1997 \\
\hline Naturalized & $\begin{array}{l}\text { Species that was originally imported from another country but } \\
\text { now behaves like a native in that it maintains itself without } \\
\text { further human intervention and has invaded native communi- } \\
\text { ties }\end{array}$ & Allaby 1998 \\
\hline Naturalized & $\begin{array}{l}\text { Species capable of reproducing and persisting in a nonindige- } \\
\text { nous region }\end{array}$ & Les and Mehrhoff 1999 \\
\hline Naturalized & Alien species that have become successfully established & Lawrence 2000 \\
\hline Naturalized & $\begin{array}{l}\text { Non-native species or race that, following escape or release, has } \\
\text { become established in the wild in self-maintaining populations }\end{array}$ & Manchester and Bullock 2000 \\
\hline
\end{tabular}

\begin{tabular}{l|lll|} 
Journal : BINV & Dispatch : 28-7-2005 & Pages : 16 \\
CMS No. : Do00020710 & $\square$ LE & $\square$ TYPESET \\
MS Code : BINV 246R1 & $\square$ CP & DISK \\
\hline
\end{tabular}


Appendix A.1. Continued.

\begin{tabular}{lll}
\hline Term & Definition & Reference \\
\hline Naturalized plants & $\begin{array}{l}\text { Alien plants that reproduce consistently (cf. casual alien plants) } \\
\text { and sustain populations over many life cycles without direct } \\
\text { intervention by humans (or in spite of human intervention); they } \\
\text { often recruit offspring freely, usually close to adult plants, and do } \\
\text { not necessarily invade natural, semi-natural or human-made }\end{array}$ & \\
& $\begin{array}{l}\text { ecosystems } \\
\text { The establishment of self-regenerating, usually expanding, pop- }\end{array}$ & Binggeli 1994 \\
& $\begin{array}{l}\text { ulations of an introduced species in a free-living state in the wild } \\
\text { Naturalized, invasive, }\end{array}$ & Holmes and Stroud 1995 \\
neophyte, adventive & $\begin{array}{l}\text { Established species which would not occur without introduction } \\
\text { Naturalized- feral }\end{array}$ & Holmes and Stroud 1995 \\
Naturalized- introduction & A successful re-establishment of a species in areas of former & Holmes and Stroud 1995 \\
Naturalized- re-establishment & $\begin{array}{l}\text { occurrence } \\
\text { Establishment of a species which occurs but does not breed }\end{array}$ & Holmes and Stroud 1995 \\
naturalized- establishment & $\begin{array}{l}\text { naturally in a given area e.g. a migrant, passage migrant or winter } \\
\text { visitor }\end{array}$ & \\
Release of animals of a species into an area in which it was & WWF 1976
\end{tabular}

Re-introduction $\quad$ The deliberate or accidental release of a species or a race into an area in which it was indigenous in historical times; or, a species or race so released

Re-introduction Intentional movement of an organism into a part of its native range from which it has disappeared or become extirpated in historic times as a result of human activities or natural catastrophe

Re-introduction

The deliberate or accidental release of a living organism into the wild in areas where that kind of organism was indigenous in historic times but is no longer present

Re-introduction

An attempt to establish a species in an area which was once part of its historical range, but from which it has been extirpated or become extinct

Re-introduction

The deliberate or accidental release of living organism(s) into the wild in areas (e.g. country, region, site, etc.) where the species or race was native but has become extinct

Re-stocking

Release of animals of a species into an area in which it is already present

Re-stocking

The deliberate or accidental release of a species or race into an area in which it is already present

Re-stocking Movement of plants or animals of a species with the intention of building up the number of individuals of that species in an original habitat

Re-stocking

The release of a living organism into the wild into an area where it is already present

Re-stocking

Invasion

A distinct form of supplementation that is undertaken for amenity purposes

The movement of plants from one area to another, and their colonization in the latter; it is analysed into migration (the actual movement), ecesis (establishment), and competition

Invasive species

An alien or translocated indigenous species which, after introduction, has spread unaided into untransformed ecosystems and may be responsible for causing an imbalance there

Invader A species that moves into and colonizes a new community

UKINC 1979

IUCN 1987

NCC 1990 as in Bullock et al 1997

IUCN 1995

Bullock et al. 1997

WWF 1976

UKINC 1979

IUCN 1987

NCC 1990 as in Bullock et al. 1997.

Bullock et al. 1997

Allred and Clements 1949

Moor and Bruton 1988

Morris 1992

Binggeli 1994 ulations of an introduced species in a free-living state in the wild

\begin{tabular}{|l|lll|}
\hline & Journal : BINV & Dispatch : 28-7-2005 & Pages : $\mathbf{1 6}$ \\
CMS No. : Do00020710 & $\varangle$ LE & $\square$ TYPESET \\
MS Code: BINV 246R1 & $\varangle$ CP & $\square$ DISK \\
\hline
\end{tabular}


Appendix A.1. Continued.

\begin{tabular}{|c|c|c|}
\hline Term & Definition & Reference \\
\hline Plant invasion & $\begin{array}{l}\text { Proliferation and persistence of a species in a new range such that it } \\
\text { has detrimental consequences (abiotic and/or biotic). This persistence } \\
\text { is not dependent on deliberate human intervention. }\end{array}$ & Mack 1996 \\
\hline Invasive species & $\begin{array}{l}\text { Nonidigenous species capable of establishing and spreading signifi- } \\
\text { cantly within natural communities }\end{array}$ & Les and Mehrhoff 1999 \\
\hline Plant invasion & $\begin{array}{l}\text { Occur when a species expands into a new range intentionally or } \\
\text { unintentionally due to human activities and is accompanied by adverse } \\
\text { economic, ecological or other effects }\end{array}$ & Sher and Hyatt 1999 \\
\hline Plant invasion & $\begin{array}{l}\text { Establishment, massive proliferation and spread of species in a new } \\
\text { range, often far removed from their native range }\end{array}$ & Mack 2000 \\
\hline Invader & $\begin{array}{l}\text { Biotic invaders are species that establish a new range in which they } \\
\text { proliferate, spread and persist to the detriment of the environment }\end{array}$ & Mack et al. 2000 \\
\hline Invasive plants & $\begin{array}{l}\text { Naturalized plants that produce reproductive offspring, often in very } \\
\text { large numbers, at considerable distances from parent plants (approx- } \\
\text { imate scales: }>100 \mathrm{~m} \text { per }<50 \text { years for taxa spreading by seeds and } \\
\text { other propagules; }>6 \mathrm{~m} \text { per } 3 \text { years for taxa spreading by roots, rhi- } \\
\text { zomes, stolons, or creeping stems), and thus have the potential to } \\
\text { spread over a considerable area }\end{array}$ & Richardson et al. 2000 \\
\hline
\end{tabular}

Invasion

Invasive

Invasive alien species

Invasive aliens

Pest

Pest species

Pest ( = plant pest $)$

Pest

Pest

Pest

Pest

Pest

Pest

Pest

Weed

Range expansions over large spatial scales

Establishing in and replacing natural habitats

Species introduced deliberately or unintentionally outside their natural habitats where they have the ability to establish themselves, invade, out compete natives and take over the new environments

Foreign species which get out of control and spread rapidly in a new environment, competing with, and often crowding out or wiping out the indigenous species which belong there

Any of the animals eating or destroying crops. All species detrimental to man

A species which has a major negative impact on the environment and does not have any desirable attributes

Any form of plant or animal life, or any pathogenic agent, injurious or potentially injurious to plant or plant products

Subjective term describing any organism that is regarded as harmful, irritating, or offensive to humans, either directly or indirectly through its effect on animals and plants

Any species, strain or biotype of plant, animal, or pathogenic agent, injurious to plants or plant products

Organism with a negative economic effect

Any species, strain or biotype of plant, animal or pathogenic agent injurious to plants or plant products

Species, viruses, bacteria and other micro-organisms considered harmful to the health of human beings, crops and other living organisms

An animal that competes with humans by consuming or damaging food, fibre, or other materials intended for human consumption or use. Many such species are harmless or ecologically beneficial, others are harmless until their populations increase rapidly in response to a virtually unlimited (to them) resource

Any species, strain or biotype of plant, animal or pathogenic agent injurious to plants or plant products

An undesirable wild plant adapted to live and reproduce rapidly under conditions of cultivation or pasture

Weed, pest

Any plant, either native or introduced, interfering with the objectives or requirements of people

Weed
Talley and Levin 2001

Simberloff et al. 2002

CBD 2004

GBWMP-SA 2004

Godman and Payne 1986

Moor and Bruton 1988

FAO 1990

Morris 1992

ISPM 1996

Williamson and Fitter 1996

IPPC 1997

UN 1997

Allaby 1998

FAO 2002

Godman and Payne 1986

Binggeli 1994

Allaby 1998

\begin{tabular}{|l|lll|}
\hline & Journal : BINV & Dispatch : 28-7-2005 & Pages : $\mathbf{1 6}$ \\
CMS No. : Do00020710 & $\square$ LE & $\square$ TYPESET \\
MS Code : BINV 246R1 & $\nabla$ CP & DISK \\
\hline
\end{tabular}


Appendix A.1. Continued.

\begin{tabular}{|c|c|c|}
\hline Term & Definition & Reference \\
\hline Weed & $\begin{array}{l}\text { Plants that interfere with management or appreciation of nat- } \\
\text { ural resources (growing where they are perceived as undesir- } \\
\text { able). Can include non-indigenous or indigenous species. }\end{array}$ & Les and Mehrhoff 1999 \\
\hline $\begin{array}{l}\text { Weeds, plant pests, } \\
\text { harmful species, problem plants }\end{array}$ & $\begin{array}{l}\text { Plants (not necessarily alien) that grow in sites where they are } \\
\text { not wanted and which usually have detectable economic or } \\
\text { environmental effects }\end{array}$ & Richardson et al. 2000 \\
\hline Transformers & $\begin{array}{l}\text { Species that change the character, condition, form or nature of } \\
\text { a natural ecosystem over a substantial area }\end{array}$ & Wells et al. 1986 \\
\hline Physical ecosystem engineer & $\begin{array}{l}\text { Organisms that directly or indirectly control the availability of } \\
\text { resources to other organisms by causing physical state changes } \\
\text { in abiotic or biotic materials }\end{array}$ & Jones et al. 1997 \\
\hline Environmental weeds & $\begin{array}{l}\text { Alien plant taxa invading natural vegetation affecting native } \\
\text { biodiversity and/or ecosystem functioning }\end{array}$ & Randall 1996 \\
\hline
\end{tabular}

\section{References}

549 Allaby M (1998) Oxford Dictionary of Ecology. Oxford 550 University Press, Oxford, 40

551 Allred BW and Clements ES (1949) Dynamics of Vegetation. 552 Selections from the Writings of Frederic E. Claments, Ph.D., 553289 pp. H.W. Wilson Co., New York

554 Binggeli P (1994) The misuse of terminology and anthropo555 metric concepts in the description of introduces species. 556 Bulletin British Ecological Society 25(1): 10-13

557 Bullock JM, Hodder KH, Manchester SJ and Stevenson MJ 558 (1997) A review of information, policy and legislation on 559 species translocation, 9 pp. Joint Nature Conservation 560 Committee Report No. 261, Peterborough

561 CBD (2001) Convention on Biological Diversity, SBSTTA 6, 562 Recommendation VI/4: Alien species that threaten ecosys563 tems, habitats or species, Annex: interim guiding principles 564 for the prevention, introduction and mitigation of impacts of 565 alien species. Retrieved from http://www.biodiv.org/recom566 mendations $/$ default.aspx? $1 \mathrm{lg}=0 \& \mathrm{~m}=$ sbstta- $06 \& \mathrm{r}=04$ on 12 567 July 2004

568 CBD (2004) Invasive Alien Species. Retrieved from http:// 569 www.biodiv.org/programmes/cross-cutting/alien/ on 12 July $570 \quad 2004$

571 Chapman JL and Reiss MJ (1999) Ecology: Principles and 572 Applications. Cambridge University Press, Cambridge, 330

573 Crooks JA (2002) Characterizing ecosystem-level consequences 574 of biological invasions: the role of ecosystem engineers. 575 Oikos 97: 153-166

576 Daehler CC (2001) Two ways to be an invader, but one is more 577 suitable for ecology. The Ecological Society of America. 578 82(1): 101-102

579 Davis MA and Thompson K (2000) Eight ways to be a 580 colonizer; two ways to be an invader: a proposed nomen581 clature scheme for invasion ecology. The Ecological Society 582 of America 81(3): 101-102

583 FAO (1990) FAO glossary of photosanitary terms. FAO Plant 584 Protection Bulletin 38(1): 5-23

585 FAO (1996) FAO Technical Guidelines for Responsible Fish586 eries - Precautionary Approach to Capture Fisheries and
Species Introductions - 2. Food and Agriculture Organization of the United Nations, Rome, 54

FAO (2003) Fisheries Management - 2. The Ecosystem Approach to Fisheries. FAO Technical Guidelines for Responsible Fisheries 4, suppl. 2. Food and Agriculture Organization of the United Nations, Rome, 112

FAO (2004) FAO Glossary. Retrieved from http://www. fao.org/glossary/ on 16 July 2004

GBWMP-SA (2004) Global Ballast Water Management Programme (GloBallast) - South Africa. Retrieved from http:// www.ballastwater-sa.org on 16 July 2004

Godman A and Payne EMF (1986) Longman Dictionary of Scientific Usage. Longman Group Ltd., Harlow, 684

Moor IJ and Bruton MN (1988) Atlas of Alien and Translocated Indigenous Aquatic Animals in Southern Africa. South African National Scientific Programmes Report 144, 310 pp

Hayes KR and Sliwa C (2003) Identifying potential marine pests - a deductive approach applied to Australia. Marine Pollution Bulletin 46(1): 91-98

Holmes JS and Simons JR (1996) The Introduction and Naturalisation of Birds. The Proceedings of the BOU's 1995. Annual Conference (April 1995) Supported by the Joint Nature Conservation Committee. HmSO, London, UK, 136

Holmes JS and Stroud DA (1995) Naturalised birds: feral, exotic, introduced or alien. British Birds 88(12): 602-603

ICES (1994) Report of the ICES Advisory Committee on the Marine Environment. Annex 3. ICES Cooperative Research Report 204, 122 pp

ICES (1995) Code of practice on the introductions and transfers of marine organisms 1994/Code de conduite du CIEM pour les introductions et transfers d'organismes marins 1994. ICES, Copenhagen, 12

ISPM (1996) Code of Conduct for the Import and Release of Exotic Biological Control Agents. Food and Agriculture Organization of the United Nations, Rome, 23ISPM Publication No. 3

IUCN (1987) The IUCN Position Statement on Translocation of Living Organisms. International Conservation Union (IUCN), Gland, 11

\begin{tabular}{|l|lll|}
\hline & Journal : BINV & Dispatch : 28-7-2005 & Pages : $\mathbf{1 6}$ \\
CMS No. : Do00020710 & $\varangle$ LE & $\square$ TYPESET \\
MS Code: BINV 246R1 & $\varangle$ CP & $\square$ DISK \\
\hline
\end{tabular}


627 IUCN (1995) IUCN /SSC Guidelines for Re-introductions. 628 IUCN, Gland, 6

629 IUCN (2000) IUCN Guidelines for the Prevention of Biodi630 versity Loss Caused by Alien Invasive Species. IUCN, 631 Gland, 24

632 IPPC (1997) International Plant Protection Convention. Food 633 and Agriculture Organization of the United Nations, Rome, 634 16New Revised Text approved by the FAO Conference at its 635 29th Session - November 1997

636 Jones CG, Lawton JH and Shachak M (1997) Positive and 637 negative effects of organisms as physical ecosystem engi638 neers. Ecology 78(7): 1946-1957

639 Kolar CS and Lodge DM (2001) Progress in invasion biology: 640 predicting invaders. Trends in Ecology \& Evolution 16: 199641204

642 Kowarik I (2003) Human agency in biological invasions: 643 secondary releases foster naturalisation and population 644 expansion of alien plant species. Biological Invasions 5: $645 \quad 293-312$

646 Lawrence E (2000) Henderson's Dictionary of Biological 647 Terms. Prentice Hall, Harlow, 719

648 Les DH and Mehrhoff LJ (1999) Introduction of nonindige649 nous aquatic vascular plants in southern New England: a 650 historical perspective. Biological Invasions 1: 281-300

651 Lockwood JL, Simberloff D, McKinney ML and Van Holle B 652 (2001) How many, and which, plants will invade natural 653 areas?. Biological Invasions 3: 1-8

654 Mack RN (1996) Predicting the identity and fate of plant 655 invaders: emergent and emerging approaches. Biological 656 Conservation 78: 107-121

657 Mack NM (2000) Cultivation fosters plant naturalization by 658 reducing environmental stochasticity. Biological Invasions 2: $659 \quad 111-122$

660 Mack RN, Simberloff D, Lonsdale WM, Evans H, Clout M 661 and Bazzaz FA (2000) Biotic invasions: causes, epidemiol662 ogy, global consequences, and control. Ecological Applica663 tions 10(3): 689-710

664 Manchester SJ and Bullock JM (2000) The impacts of non665 native species on UK biodiversity and the effectiveness of 666 control. Journal of Applied Ecology 37: 845-864

667 Marco DE, Păez SA and Cannas SA (2002) Species invasive668 ness in biological invasions: a modelling approach. Biolog669 ical Invasions 4: 193-205

670 Mooney HA and Hobbs RJ (2000) Invasive Species in a 671 Changing World. Island Press, Washington, 457

672 Moore CG (1999) Aedes albopictus in the United States: current 673 status and prospects for further spread. Journal of the 674 American Mosquito Control Association 15(2): 221-227

675 Morris C (1992) Academic Press Dictionary of Science and 676 Technology. Academic Press, San Diego, 2432

677 Mühlenbach V (1979) Contributions to the synanthropic 678 (adventive) flora of the railroads in St. Louis, Missouri, 679 U.S.A. Annals of the Missouri Botanical Garden 66(1): 1-108

680 NCC (1990) Review of NCC policy on species translocations in 681 Great Britain. Unpublished report, Nature Conservancy 682 Council. (NCC BS P9021). In: Bullock JM Hodder KH 683 Manchester SJ and Stevenson MJ (1997) A review of information, policy and legislation on species translocation. Joint Nature Conservation Committee Report No. 261, Peterborough, 9 pp

Pyšek P (1995) On the terminology used in plant invasion studies. In: Pyšek P, Prach K, Rejmánek M and Wade M (eds) Plant Invasions: General Aspects and Special Problems, pp 71-81. SPB Academic Publishing, Amsterdam

Randall JM (1996) Defining weeds of natural areas. In: Luken JO and Thieret JW (eds) Assessment and Management of Plant Invasions, pp 18-25. Springer Verlag, New York

Richardson DM, Pyšek P, Rejmánek M, Barbour MG, Panetta FD and West CJ (2000) Naturalization and invasion of alien plants: concepts and definitions. Diversity and Distributions 6: 93-107

Sandlund OT and Bongard T (2000) The freshwater environment. In: Weidema IR (eds) Introduced Species in the Nordic Countries, pp 87-122. Nord Environment 2000: 13, Nordic Council of Ministers, Copenhagen

Schwartz MW (1996) Defining indigenous species: an introduction. In: Luken JO and Thieret JW (eds) Assessment and Management of Plant Invasions, pp 7-17. Springer Verlag, New York

Sher AA and Hyatt LA (1999) The distribution resource-flux invasion matrix: a new framework for patterns of plant invasion. Biological Invasions 1: 107-114

Simberloff D, Relva MA and Nuňes M (2002) Gringos en el bosque: introduced tree invasion in a native Nothofagus/ Austrovedrus forest. Biological Invasions 4: 35-53

Starfinger U, Kowarik I, Rode M and Schepker H (2003) From desirable ornamental plant to pest to accepted addition to the flora? - the perception on an alien tree species through the centuries. Biological Invasions 5: 323-335

Sutinen JG (2000) A framework for monitoring and assessing socioeconomics and governance of large marine ecosystems. NOAA Technical Memorandum NMF S-NE-158, 32 pp

Talley TS and Levin LA (2001) Modification of sediments and macrofauna by an invasive marsh plant. Biological Invasions 3: $51-68$

UKINC (UK Committee for International Nature Conservation) (1979) Wildlife Introductions to Great Britain. Nature Conservancy Council, Peterboroguh, U.K., 22

United Nations (1997): Glossary of Environmental Statistics. Studies in Methods, Series F, No. 67, 83 pp

Webb DA (1985) What are the criteria for presuming native status?. Watsonia 15: 231-236

Wells MJ, Poyton RJ, Balsinhas AA, Musil CF, Joffe H, Hoepen Evan and Abbott SK (1986) The history of introduction of invasive alien plants to southern Africa. In: Macdonald IAW, Kruger FJ and Ferrar AA (eds) The Ecology and Management of Biological Invasions in Southern Africa, pp 21-35. Oxford University Press, Cape Town

Williamson M (1996) Biological Invasions. Chapman \& Hall, London, 244

Williamson M and Fitter A (1996) The varying success of invaders. Ecology 77(6): 1661-1666

WWF (1976) Reintroductions: Techniques and Ethics. Proceedings of the Seminar, Rome, June 1976, 300 pp

\begin{tabular}{|l|lll|}
\hline Journal : BINV & Dispatch : 28-7-2005 & Pages : 16 \\
CMS No. : Do00020710 & $\square$ LE & $\square$ TYPESET \\
MS Code : BINV 246R1 & $\square$ CP & DISK \\
\hline
\end{tabular}

